\section{$\boldsymbol{G}$

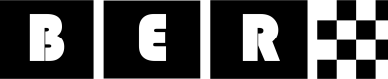

Entrepreneurial Business and Economics Review

2019, Vol. 7, No. 4

\title{
Internationalisation as Institutional Escape for Family Businesses in Conflict Zones: Evidence from Afghanistan
}

\author{
Muska Hanify, Omar Al Serhan, Sarath W.S.B. Dasanayaka, \\ Kimberley Catherine Gleason
}

\begin{abstract}
A B S T R A C T
Objective: The objective of this article is to investigate the use of internationalisation to "escape" the institutional voids present in conflict economic systems, through interviews with fifteen Afghan family business leaders who run businesses in Kabul.

Research Design \& Methods: Relying on grounded theory, we explore the role of internationalisation in providing security and stability for family businesses in conflict zones. In total, fifteen family business leaders were interviewed by three members of the research team working in pairs, after an analysis of transcripts subsequently described over the course of the interview process.
\end{abstract}

Findings: We find that Afghan family business leaders demonstrate interest in internationalisation as a method of escaping institutional voids in the domestic environment, and that their most commonly cited motive in doing so is to obtain legitimacy in foreign markets through the establishment of quality standards.

Implications \& Recommendations: The appropriate way to proceed with internationalisation is to follow a stepwise process, so that family business leaders can draw upon both strengths inherent in their family and also engage in organisational learning through relationships with family businesses in neighbouring countries with similar cultures.

Contribution \& Value Added: We contribute to institutional theory by advancing our understanding of how insecurity, lawlessness, and tribalism play a role in the internationalisation of family businesses in conflict zones and to the family business literature by documenting how family business internationalisation is a response to domestic institutional voids.

\section{Article type: research article}

Keywords:

entrepreneurship; business internationalisation; family business; conflict zones; Afghanistan institutional theory

JEL codes: $\quad$ M10, M16, F3, Y8

\section{Suggested citation:}

Hanify, M., Al Serhan, O., Dasanayaka, S.W.S.B., \& Gleason., K.C. (2019). Internationalisation as Institutional Escape for Family Businesses in Conflict Zones: Evidence from Afghanistan. Entrepreneurial Business and Economics Review, 7(4), 91-116. https://doi.org/10.15678/EBER.2019.070406 


\section{INTRODUCTION}

Afghanistan has been consumed by distinct waves of violent conflict within the lifetime of an Afghan towards the end of his or her life expectancy of sixty years: the Soviet/American proxy war in the 1980s, the brutal Taliban rule, which killed over a million people and ended in 2001, and the US occupation and ensuing insurgency, which may presently be giving way to an even more ominous regime consisting of the Islamic State and the Taliban. As of 2018, the Afghan is the world's least powerful passport in terms of the number of countries that permit Afghan entry without a visa (Global Passport Power, 2019). Over half of the population lives in poverty, the unemployment rate is $40 \%$, financial capital for business development is extremely scarce, while corruption is among the worst in the world (World Bank, 2019). Suicide bombings are familiar events even in the heavily protected Green Zone of Kabul.

Institutional theory provides a theoretical basis for assessing internationalisation by conflict zone family-owned businesses. In particular, given the characteristics of the Afghan economic and social environment, we argue that the co-option of formal institutions of governance and jurisprudence by oppressive, powerful forces creates an opportunity for Afghan family business leaders to engage in "institutional escape" through the establishment of foreign markets. The aim of this paper is to provide insights into how conflict zone family business leaders perceive internationalisation. Through a qualitative research method, we interview fifteen Afghan family business leaders and obtain insights into how internationalisation is viewed as a survival strategy in the context of the stage model theory.

The importance of this research lies in its implications for family business leaders in conflict zones and failed states worldwide. From a practical perspective, our results have implications for various levels of government in Afghanistan and for nongovernmental organisation in terms of supporting internationalisation; from a theoretical perspective, we identify a gap in the literature by documenting how warlords in country tribalism - referred to as "the Mafia" by our sample participants - and extreme resource constraints (cf. Arregle, Duran, Hitt, \& Van Essen, 2017) limit the volition of families in governing these enterprises. Exposure to new products, markets, and ideas which occurs due to internationalisation is significant, but also critical is the opportunity to observe how business functions in "normal" peace-time environments. These insights cannot be obtained in Afghanistan, thus necessitating internationalisation. Foreign development aid should promote the interests of these family businesses in supporting the establishment of a framework for establishing export markets and partnerships in non-conflict zone neighbouring countries.

The paper proceeds as follows. In the framework of an exploratory study, we first describe the literature on the subject of family business and internationalisation and present our research questions. We then present the materials and methods used in our analysis of our research questions. Our results and discussion follows, and we conclude the paper, in which we provide limitations of the study, along with recommendations for subsequent research and for policymakers based on our findings. 


\section{LITERATURE REVIEW}

\section{Institutional Theory and Family Owned Businesses}

The family business is the most enduring organisational business structure, comprising $80 \%$ to $98 \%$ of world's businesses according to Poza (2013), who reviews the social science research on family-owned firms. A family business means a set of individuals from a family who work or own the same business. It can be difficult to distinguish family business from other businesses in terms of operations and objectives; although a number of definitions exist (Bouges, 2013; Poutziouris, Smyrnios, \& Klein, 2008; Kemppainen, 2011; Short, Payne, Brigham, Lumpkin, \& Broberg, 2009). Each of these studies propose own definitions after a review of the relevant literature. We rely on the definition proposed by Chua, Chrisman, and Sharma (1999), which posits that, "The family business is a business governed and/or managed with the intention to shape and pursue the vision of the business held by a dominant coalition controlled by members of the same family or a small number of families in a manner that is potentially sustainable across generations of the family or families." 1

In a theoretical framework, Casson (1999) argues that the defining characteristics of family-owned businesses lie in the cohesion generated by the dynastic motive, which encourages trust among family members across generations. De Massis Kotlar, Mazzola, Minola, and Sciascia (2018a) review recent studies on family-owned firms, and explain that recent research indicates that these features involve family business leaders pursuit of noneconomic goals (Kotlar \& De Massis 2013; De Massis et al., 2018a) and the centralisation of administrative of control (Carney 2005). The features of family-owned firms regarding emotional investment in the business and dynastic intention are tied to "patient capital" (De Massis et al., 2018a) - a willingness to invest long-term rather than to meet quarterly earnings numbers - and superior governance relative to non-family-owned firms, which is revealed through lower agency costs, as document empirical analyses (Denis, Denis, \& Sarin, 1999; Chrisman, Chua, \& Litz, 2004). Furthermore, family-owned firms tend to exhibit strong family brand identity and greater depth of knowledge of the business (Miller \& Le Breton-Miller, 2005). These same features also lead family-owned business leaders to exhibit greater risk aversion (Casson, 1999) and to be more conservative in decision-making (Gómez-Mejía, Makri, \& Larraza-Kintana, 2010). Moreover, family firms face greater resource constraints in terms of the availability of professional management (Graves \& Thomas, 2008) and financial capital (Anderson \& Reeb, 2003).

Institutional theory argues that "structures - however defined - do matter" (Peters, 2012), whether formal structures of government or informal structures rooted in cultural values. The family business is an institution grounded in family governance through the control of decision rights in some form; i.e., through the nuclear family, kinship group, or ownership of equity in the case of external professional management (Leaprott, 2005). An external institution - such as the government, insurgents, or organised crime groups - can engage in coercion of the family business in order to achieve a legitimacy of its own. The family business structure is a means to fulfil needs beyond simply security, but also the self-actualisation of family members (Leaprott, 2005).

${ }^{1}$ All of our sample Afghan SMFEs meet these criteria. 
Institutional theory also argues that formal institutions seek legitimacy from values present in the cultural framework by "acting collectively" on shared values (Meyer \& Rowan, 1977). From an institutional perspective, a misalignment can develop between the institutions of the formal and cultural sectors, such as laws and rules established through the justice system and government and - for cultural sectors - including the values held as cultural norms. When this misalignment occurs, institutional voids are created (Mair \& Marti, 2009). These voids can remain empty, thus requiring strategic behaviour from firms to compensate for it, or it can be filled with a variety of pro- or anti-social institutions.

Family is the single most important institution in the Afghan society (Dupree 1997; Muller \& Paulien 2011; Omidian, 1996; Smith, 2009), which is relied upon as the primary source of economic and socioeconomic capital. Afghan is a collectivist society, in which important decisions related to business and social dealings are determined within the family. The extended family is one's social environment, with agency over personal decisions such as marriage, educational decisions, and migration decisions, while families represent a "harbor of trust and comfort that cannot be found elsewhere" (Fisher, 2013). Family-owned firms employ more than one-third of the Afghan population eligible for work (Mashal, 2014). Therefore, from an institutional theory perspective, a family is the central platform for business organisation in less developed countries without functioning external capital markets, so family businesses face compelling "institutional voids" in terms of traditional mechanisms of economic and political governance, as these are either absent or extremely corrupt. Business in Afghanistan exhibits a curious duality: it simultaneously refers to the corruption of political leadership as an illegitimate sector network (i.e. through a warlord, clan, or "mafia") and to the natural context of an extended family business as a source of support for economic and social activity (Ahmad, 2018). In a sense, the "family business" can either represent the most enduring human organisation or a pervasive and oppressive force that undermines access to capital and economic growth in order to retain power. A family business leader in this context may wonder what kind of opportunity exists for his or her business and the future generations who might run the business. The literature in conflict zone entrepreneurship indicates that the available choices for survival often boil down to becoming either predator or prey (Sanders \& Weitzel 2013).

Institutional theory has been applied to describe circumstances in which internationalisation, such as trade or foreign direct investment, occurs due to institutional voids in the local environment. Bhaumik, Driffield, and Pal (2010) and Carney, Duran, van Essen, and Shapiro (2017) argue that the country specific formal and informal institutional attributes contribute to the decision to internationalise. For instance, Dunning (1996) argues that outward foreign direct investment occurs to escape burdensome restrictions at home, while Caves (1996) makes a similar argument regarding tax regimes. Schoppa (2008) finds that outward FDI is a form of escape from onerous institutional environments. Gordon and Hines (2002) show that companies relocate their nation of incorporation to avoid oppressive taxation regimes.

The Afghan economic ecosystem can be considered a "warlord economy" in that it suffers from characteristics of institutional failure common to conflict zones: lawlessness, corruption, and poverty. In this environment, a predator-prey relationship forms when powerful entities co-opt the institutions of governance towards rent-seeking activities, 
and divert economic resources generated from extortion, fraud, kidnapping, and terrorism towards entrenching own power. In these environments, the warlord takes the place of the state and diverts economic activity to maintain control. At low levels of economic development, when respect for property rights is low, these warped institutions gather strength and the economic system evolves to the point where the government and judicial system themselves become tools of the warlords (Mehlum, Moene, \& Torvik, 2003). To survive, entrepreneurs in the warlord economy must choose between joining the warlords or becoming prey, if they wish to remain in the domestic environment (Sanders and Weitzel, 2013). However, we argue that internationalisation is a mechanism to escape the situation - and thereby avoid being predator or prey - for family businesses in conflict zones such as Afghanistan.

\section{Family-Owned Firms and Escape through Internationalisation}

Many family-owned businesses acknowledge that internationalisation is an important step to business success, stability, and expansion (Claver, Rienda, \& Quer, 2009). However, rather than strictly economic objectives, it is considerations of the socioeconomic wealth of the family (status, emotional attachment, control over decision-making, social relationships with stakeholders) that may lead family firms to neglect internationalisation and focus on domestic markets (Gomez-Mejia, Haynes, Núñez-Nickel, Jacobson, \& Moyano-Fuentes, 2007; De Massis, Kotlar, Wright, \& Kellermanns, 2018a). Greater risk aversion exhibited by family-owned firms may also preclude "taking chances" outside of the norm, while human capital and financial capital constraints may further preclude internationalisation. Graves and Thomas (2008) argue that family business leaders exhibit some level of dissonance regarding ties to their home country and interest in globalisation.

The literature on family business internationalisation shows that Afghan family businesses encounter a variety of constraints that inhibit their ability to grow even in the most conducive operating environments, including limited access to financial and human capital and an unwillingness to share control with outsiders. For a nontrivial part of the population, the main challenge that family businesses face is the constant threat of physical violence due to war, armed insurgency, or hostile occupation. Thus, family business groups must leverage the operational advantages they have from the family structure in these conflict environments to ensure the survival of their business but also the family itself. However, domestic and global policymakers do not prioritise support of internationalisation by family-owned firms, because the government pays more attention to strategies related to imports. As a result, the export orientation of Afghan businesses has been largely neglected. In terms of escape, internationalisation may help Afghan family businesses generate stable cash flows when local demand is low, decrease production costs, and enter low cost markets.

Furthermore, institutional environments, in which social structures, rules, cultural norms, and routines establishes authoritative guidelines for social behaviour and - according to Yang and Su (2014, p. 721) - the authoritative guidelines which are the constructs of institutional theory, "exert significant effects on organisational behaviour, structure, strategy, governance, and process," which may also play a role in the intentions of these family businesses to internationalise. Thus, from the perspective of Arregle et al. (2017), the resource set required for successful internationalisation is either non-existent or extremely weak. 
Therefore, for family-owned businesses to internationalise, family business leaders must anticipate benefits that outweigh their natural tendency towards conservatism. Further, Verbeke and Kano (2012) and Hennart, Majocchi, and Forlani (2017) argue that given an optimal level of internationalisation for each firm - research should assess the conditions under which family-owned firms move towards or away from the optimal level. Institutional theory provides a framework for assessing the trade-offs associated with internationalisation in conflict zones, where warlord economy effectively filled the institutional void. It is a means of escape for the family from the institutions absent in the home country or, as Gomez-Mejia et al. (2007) argues, geographically concentrated business risks. Furthermore, the long-term orientation that generates "patient capital" of familyowned businesses may benefit them in terms of long-term planning required to successfully internationalise and escape the institutional voids.

In sum, the domestic institutional infrastructure in Afghanistan presents many challenging voids filed by anti-social entities - such as drug lords and other organised crime networks, the Islamic State, and the Taliban - which creates a need for escape with the use of the unique institutional qualities of family-owned businesses. However, the characteristics of familyowned businesses generate socioeconomic trade-offs to internationalisation. Therefore, our first research question relates to institutional theory and the perception of the net effect of trade-offs of internationalisation by Afghan family businesses:

RQ1: Given the institutional voids present in Afghanistan, how do Afghan family business leaders view internationalisation?

Institutional theory describes the nature of institutional voids, from which entities escape. In the Afghan context, many functioning institutions are at best absent and, at worst, co-opted by the warlord economy. On any given day, an academic in the West might notice news related to a suicide bombing or insurrection in Afghanistan. In fact, the Suicide Attack Database of the University of Chicago identifies 1164 suicide attacks in Afghanistan, causing 5427 deaths and 13885 injuries, with a kill rate yield of 4.7 per attack, between 1974 and 2016, making it a fairly routine event that Afghan business owners have to live with (http://cpostdata.uchicago.edu/search_results_new.php). Referred to as the "city of concrete blast T-walls" among the expats who live there, Kabul is one of the least hospitable capitals on Earth in which to do business from a number of perspectives, including weak security conditions, corruption, instability, infrastructure problems, a low educational level, and high poverty. What opportunities for long-term growth are available to family business leaders in on ongoing war zone characterised by a population of 36.6 million, half of which is under the age of 21 and has never experienced a peacetime environment, $70 \%$ of which is illiterate, and where the life expectancy is below 60 years of age? At present, family businesses in Afghanistan operate only in their local markets - Kandahar or Kabul although some have facilities and distribution throughout the country, while most find it difficult to internationalise due to many resource constraints. As one of the poorest countries in the world, demand for products and services of Afghan SMFEs is chronically low. Sociocultural constraints on women further reduce the ability of Afghan SMFEs to grow and expand even in the local market, not to mention abroad.

The literature uncovers a number of characteristics, which limit family businesses in pursuing internationalisation. Arregle et al. (2017) summarise the family business interna- 
tionalisation literature, observing a distaste by families for outside knowledge and resources. This restriction on assets and human capital results in a lower orientation towards internationalisation of family-owned firms. Pukall and Calabrò (2014) argue that risk perception and interest in socioeconomic wealth impacts the manner in which family-owned business internationalisation proceeds. Calabrò, Torchia, Pukall, and Mussolino (2013) argue that at very high levels of family ownership, managers of family-owned firms exhibit greater risk aversion and greater reluctance to pursue internationalisation, while Calabrò, Campopiano, Basco, and Pukall (2017) find that German family business owners obtain external human capital to navigate the internationalisation process. In Afghanistan, given the low educational level even in the capital, outside expertise in modern management practices would be difficult for a family business to obtain domestically. The human capital void present in Afghanistan would make it difficult to internationalise successfully, but on the other hand, the relatively high educational indicators in neighbouring countries provides an opportunity for businesses who manage to internationalise to obtain the managerial talent pool to succeed.

At the same time, internal and external challenges for Afghan family business owner survival in Afghanistan have increased, while questions remain regarding the competitiveness of local businesses and their ability to survive large-scale political transitions in a system dominated by warlords. Compounding the problem of the prioritisation of import substitution by the government at the expense of the development of a formal export sector is collusion in the grey market. Between $70 \%$ to $80 \%$ of exports are unregistered, and thereby operate beyond the periphery of the formal economy (Mashal, 2014). The wealth maximisation strategy for these businesses involves the export of their products through a "mafia of exporters" called the "Commission," which negatively affects the quality of products and revenue of the country (Mashal, 2014). Our second research question seeks to identify which aspects of institutional voids in Afghanistan's warlord economy are the most critical push (or exo) considerations for escape for Afghan family business leaders.

RQ2: Which institutional voids in Afghanistan provide the strongest motivation for Afghan family business leaders to escape through internationalisation?

Theories of internationalisation differ in terms of their predictions for which characteristics of businesses lead to successful internationalisation. In that the internationalisation of entrepreneurial ventures is based on the entrepreneur's unique proximity to customers and markets that support the business, Afghan family-owned business leaders may have unique knowledge-based assets that could allow them to internationalise. As posited by Antoncic and Hisrich (2000), the human and social capital of entrepreneurs who work for the SMFE sector may facilitate internationalisation. For instance, borders between Afghanistan and Iran or Afghanistan and Pakistan are relatively porous, while their respective languages are comparable. There is a large expatriate Afghan community in several countries that border Afghanistan, among which community, family, tribal, and social ties could facilitate business exchange. On the other hand, the previously mentioned stability and security situation is such that Afghan SMFEs may not have the luxury of considering expansion in Afghan provinces, not to mention foreign markets. Pukall and Calabrò (2014) argue that risk perception and interest in socioeconomic wealth impacts the manner, in which family-owned business internationalisation proceeds. Furthermore, many family firms that internationalise prefer to do business with other family businesses in their target foreign markets, possibly because 
they have comparable governance, shared values, incentive alignment, and objectives, which helps to bridge national borders and cultural barriers between them (Okoroafo, 2010). This tendency towards isomorphism is likely better executed in neighbouring countries, which share similar cultural features like language.

The strategies for internationalisation of Afghan family-owned businesses are also tied to the unique characteristics of family-owned firms and to the institutional voids they seek to escape. Gomez- Mejia, Makri, and Larraza-Kintana (2010) argues that family firms prefer to internationalise in geographically and culturally similar environments. Hernandez, Nieto, and Boellis (2018) find that family-owned firms seek locations for internationalisation with greater institutional quality, consistent with the idea of institutional escape. Yamanoi and Asaba (2018) find evidence that host country institutional quality as measured by the level of corruption also impacts entry strategy, in that high levels of host country corruption are significantly and positively correlated with greenfield investment versus acquisitions. However, these studies focus on firms from the West or Japan, and little remains known about internationalisation strategies of conflict zone entrepreneurs.

The literature on internationalisation argues that firms choose from several different processes to extend their reach beyond borders. The network approach developed by Johanson and Mattson (1988) argues that the internationalisation process is based on building relationships and maintaining them for the purpose of attaining the organisation's objectives. Network relationships inspire and influence firms to internationalise and creates the opportunity to get market specific information and establish a supply chain in the foreign market. It also helps the firm obtain business and political contacts establish reputational capital through earning trustworthiness and reliability in the new market. Among others, Hennart (2014) describes the sudden internationalisation of "Born Global" firms, who internationalise from inception. Varghese (2015) states that there are five stages of internationalisation in the staged theory: (1) the development of the local or domestic market to the point when a firm gains production and financial confidence through organisational learning; (2) market research; (3) planning process, in which the company chooses its target country for the business expansion; (4) the establishment of the primary plan for entering the potential market, often implemented by starting with a small amount of exports to the target country and then extending the businesses if the primary plan for entering the market is successful; and, lastly, (5) using ownership intensive foreign direct investment like acquisitions, strategic alliances, and joint ventures. Hence, our third research question addresses the strategies considered ideal for Afghan family business owners to pursue internationalisation:

RQ3: What internationalisation processes do Afghan family business leaders believe provide the best means of institutional escape?

The bottom line for any business owners is the value of the firm to the owners, and Afghan business owners rightly seek the best ways not only to escape the current institutional void that hinders their progress and growth in the domestic market but also to generate income from different streams as a safety measure to mitigate the ever deteriorating domestic political, economic, and security environment. Hence, this question explores the strategies considered ideal for Afghan family business owners to pursue internationalisation. 


\section{MATERIAL AND METHODS}

In this study, we adopt grounded theory and qualitative research methodology by employing the interviewing method of data collection to obtain family business leaders' first person perspectives on internationalisation. The survey was pilot tested on a sample of MBA students at a university in Kabul, then administered in compliance with the university's Internal Review Board processes. An initial sample of firms was obtained from the Afghanistan Chamber of Commerce and Industry.

Firms from the list were contacted by phone and email to obtain recommendations for survey participants, after which snowball sampling yielded additional family business leaders of firms divided into six broad industry categories: textiles, agriculture, food and beverage, manufacturing, transportation, and services. As there is limited research relating to this study and its location, a convenience sampling approach was adopted in the form of conventional snowball sampling technique for the qualitative stage of this study. Conventional snowball sampling technique is known as a technique, in which one person provides the researcher with the name of another person to take part in the research and, in turn, this latter person provides the name of a third person to the researcher, and so on (Vogt, 1999). As documented by Bullough, Renko, and Myatt (2017), whose research involves interviews with Afghan entrepreneurs, snowball sampling is often the only way to obtain a sample in a danger zone environment with a low literacy rate and high suspicion of outsiders; mainly because Afghanistan is a "hard to reach population" - according to Marpsat and Razafindratsima (2010) - in that its population is hard to identify, has no sampling frame, and its behaviour is unknown. The combination of these elements may lead to a poor selection of participants or places to approach them. This sampling technique is a non-probability sampling technique, in which research participants are identified and recruited by identifying a few individuals from the research population, and then asking those individuals to refer other qualified individuals. To minimise bias in this stage of data collection, the researchers' first contacts were not interviewed; however, they were asked to refer qualified subjects to participate.

Five firms were then randomly selected from each of the six industry categories to be contacted by phone to obtain consent for a preliminary phone interview, followed by a personal interview with purposive sampling, in which people those are selected for interviews who have different experiences, behaviours, qualities, and attributes. The reason for choosing this type of sampling was to gain a wide range of insights in order to examine the factors that influence the internationalisation of these businesses and methods for confronting challenges from several perspectives.

Two interviews per business leader - one by phone and one in person - were done to examine differences between the two interviews and reduce potential bias. As for data validation and reliability, we conducted a comprehensive review of the available literature and the designs and methods it used to collect data, as special attention was paid to ensure that the face-to-face questions were valid, smoothly communicated, and offered an accurate representation research problem. Furthermore, as there are three spoken main languages in Afghanistan, participants were also given the choice of languages they would use, as offering this option was thought to enable better communication during each interview. The research team explained to each of interviewees that the intended interviews 
were for academic purposes only and no personal identity information would be collected at their request beyond first names and company industry.

The total of fifteen family business leaders were interviewed by three members of the research team working in pairs, after the analysis of transcripts subsequently described over the course of the interview process revealed comparable themes with no new information (cf. Creswell, 2013) and given the logistical and security constraints confronted by the research team in travelling throughout the city during the insurgency. Each phone interview lasted for approximately 15 minutes and each in person interview lasted 45 minutes.

Primary data were collected through structured interviews of these fifteen family business leaders. This study adopted Yin's (2003) approach, as this is an exploratory case study of 15 family business leaders in the Afghan capital city of Kabul. Exploring internationalisation opportunities and challenges faced by Afghan family businesses are complex phenomena from an Afghan perspective not only for geographical or demographic reasons but also for safety and security reasons. Yin $(2003$, p.3) argues that, "the distinctive need for case studies arises out of the desire to understand complex social phenomena," and we strongly believe that the context of the current study is truly a complex phenomenon. Furthermore, this study follows an interpretive approach to data analysis, which assumes that our social reality is shaped by human experiences and social contexts, which are not singular or objective. Hence, in-depth interviews were conducted to explore these human experiences and support the findings of the study.

The interviews were recorded and converted into transcripts. Data was aggregated and organised based on themes identified during the literature review and - for data analysis - we followed a deductive approach, which involves data analysis based on predetermined themes and research questions developed from the literature review. The research questions were our guide for grouping and analysing the data.

We then conducted a thematic analysis using Nvivo software, which is a software for categorizing, analysing, and reporting data. The coding process in grounded theory is done in three steps: (1) transcripts are categorised at the initial stage called open coding; (2) the relation between the primary codes is established, which is called axial coding; and (3) the categories are merged to establish a theory called selective coding (Kothari, 2004).

Open coding was conducted by two researchers independently and repeatedly reading the transcripts to classify the data, during which each researcher wrote detailed memos regarding coding structures; next, the researchers compared reflective comments on the transcripts to better identify important themes in the text. Then, interrelations between data segments were mapped and key themes were tabulated. Refinements were made using axial coding in Nvivo. This allowed us to summarise the central themes of the collected data, so that pattern identification could be followed to group these identified patterns into the themes that were connected to our research questions.

Finally, another faculty member experienced in qualitative methods reviewed the transcripts, memos, and notes in order to verify that the analysis was conducted properly. SPSS 25.0 was used for subsequent data analysis. Moreover, during data analysis, the team followed a minimum inference strategy as proposed by Seale (1999) to eliminate possible bias originating from the research team's own assumptions of participants' viewpoint on presented issues. While common method bias may be a consideration in all qualitative 
research, we hope to minimise the effect of this bias by using several different information gathering techniques and multiple interviewers.

The first 14 questions included the demographics and information about the businesses, so as to identify he current business situation and condition, discover what challenges the business faces in the domestic country, and find out what strategies the businesses implement for growth and stability. The motive for these questions were to identify the influencing factors which affect internationalisation of the SMFEs in Afghanistan. The other 11 questions of the interview were to ask about the planning and implementation strategies used by the businesses leaders for the internationalisation. Sample descriptive characteristics are provided in Table 1.

Table 1. Characteristics of Surveyed Afghan SMFEs

\begin{tabular}{|c|c|c|}
\hline \multicolumn{3}{|l|}{ Panel A } \\
\hline Generation & Number of firms reporting & $\%$ of firms reporting \\
\hline First & 13 & $86.67 \%$ \\
\hline Second & 2 & $13.33 \%$ \\
\hline \multicolumn{3}{|l|}{ Family members employed } \\
\hline$<3$ & 1 & $6.67 \%$ \\
\hline $3-5$ & 10 & $66.67 \%$ \\
\hline$>5$ & 4 & $26.67 \%$ \\
\hline \multicolumn{3}{|l|}{ Woman Owned } \\
\hline Yes & 2 & $13.33 \%$ \\
\hline No & 13 & $86.67 \%$ \\
\hline Total & 15 & $100 \%$ \\
\hline \multicolumn{3}{|l|}{ Panel B } \\
\hline Sector & Number of firms reporting & $\%$ of firms reporting \\
\hline Flour/Soybean & 1 & $6.67 \%$ \\
\hline Industrial breads & 1 & $6.67 \%$ \\
\hline Agriculture & 1 & $6.67 \%$ \\
\hline Medical equipment & 1 & $6.67 \%$ \\
\hline Honey & 2 & $13.33 \%$ \\
\hline Handcrafts and Carpets & 1 & $6.67 \%$ \\
\hline Confectionery & 1 & $6.67 \%$ \\
\hline Food processing & 1 & $6.67 \%$ \\
\hline Engineering services & 1 & $6.67 \%$ \\
\hline Construction/road design & 1 & $6.67 \%$ \\
\hline Fabrics & 1 & $6.67 \%$ \\
\hline Tailoring & 3 & $20.00 \%$ \\
\hline Total & 15 & $100 \%$ \\
\hline
\end{tabular}

Source: own study.

As shows Table 1, Panel A, most of the sampled family businesses (13 out of 15) are owned and run by the first generation, i.e. the founders, with the remaining founded by parents. Most firms in the sample employ between 3 and 5 family members. In two of the fifteen firms surveyed, the founder business leader is a woman. Panel B of Table 1 provides 
the sample breakdown by industry. The sample contains businesses from business lines such as agriculture, tailoring, construction engineering, food processing, medical equipment, honey cultivation, fabrics, and clothing. While different firms in Kabul face challenges unique to their particular industry, we attempt to identify the interrelated themes common to Afghan family businesses regarding internationalisation.

\section{RESULTS AND DISCUSSION}

While the Afghan environment is characterised by vast institutional voids, literature on family business internationalisation indicates that Afghan family businesses may face skill deficits that would make internationalisation difficult, including the lack of access to external human capital. Our first research question explores how internationalisation is viewed by Afghan family business leaders in light of institutional theory. Details related to the internationalisation status and plans of surveyed SMFEs are shown in Table 2.

Table 2. Current Internationalisation Status and Plans

\begin{tabular}{|c|c|c|}
\hline & Number & $\%$ \\
\hline \multicolumn{3}{|l|}{ Present Status } \\
\hline Presently Internationalised & 2 & $13.33 \%$ \\
\hline China & 1 & $6.67 \%$ \\
\hline Pakistan & 2 & $13.33 \%$ \\
\hline Iran & 1 & $6.67 \%$ \\
\hline Turkey & 1 & $6.67 \%$ \\
\hline Presently Not Internationalised & 13 & $86.67 \%$ \\
\hline \multicolumn{3}{|l|}{ Foreign experience of Owner } \\
\hline Yes & 3 & $20.00 \%$ \\
\hline No & 12 & $80.00 \%$ \\
\hline \multicolumn{3}{|l|}{ Outside partner } \\
\hline Yes & 5 & $33.33 \%$ \\
\hline No & 10 & $66.67 \%$ \\
\hline \multicolumn{3}{|l|}{ Plans } \\
\hline None & 3 & $20.00 \%$ \\
\hline Yes & 12 & $80.00 \%$ \\
\hline \multicolumn{3}{|l|}{ Same culture beneficial } \\
\hline Yes & 13 & $80.00 \%$ \\
\hline No & 2 & $20.00 \%$ \\
\hline Total & 15 & $100 \%$ \\
\hline
\end{tabular}

Source: own elaboration.

Among the fifteen SMFE owners surveyed, we found that two currently have foreign operations - one in Turkey, Pakistan, and Iran, another in Pakistan and China - while another one closely cooperates with European firms to purchase medical equipment. These firms had founders who worked abroad: one in Turkey in textiles and another in Iran in tailoring. Furthermore, twelve (80\%) hoped to internationalise. Only three (20\%) expressed no will or interest to internationalise at the present time. However, thirteen of the fifteen surveyed 
family businesses responded positively when asked about either expanding or initiating internationalisation, with two stating that they perceive it negatively due to concerns about their business survival in the short term. This provides some surprising insights that suggest that Afghan family business leaders perceive advantages to internationalisation that overcome the tendency of family businesses towards risk aversion.

A summary of the perceptions of motives for internationalisation of surveyed business leaders is shown in Table 3.

Table 3. Perceived benefits from internationalisation

\begin{tabular}{|l|c|c|}
\hline \multicolumn{1}{|c|}{ Perceived Benefit } & $\begin{array}{c}\text { Number } \\
\text { of responses }\end{array}$ & $\begin{array}{c}\text { \% of Firms Identifying } \\
\text { the Benefit }\end{array}$ \\
\hline $\begin{array}{l}\text { Legitimacy (Quality of products will improve due to inter- } \\
\text { national standards) }\end{array}$ & 8 & $53.3 \%$ \\
\hline National pride (Familiarise foreigners with products) & 3 & $20.0 \%$ \\
\hline Insufficient demand (Greater stability in foreign markets) & 3 & $20.0 \%$ \\
\hline $\begin{array}{l}\text { Expansion of networks for future business/ development } \\
\text { of supply chains for future relationships }\end{array}$ & 1 & $6.7 \%$ \\
\hline Greater chances for innovation & 1 & $6.7 \%$ \\
\hline None mentioned & 3 & $20 \%$ \\
\hline
\end{tabular}

Source: own study.

Surprisingly, the most common theme related to the perceived reasons for internationalisation is that it would lead to business stability through an improvement in the quality of processes and products that meet international standards. As stated by one of the survey participants, Haji Qaher, whose family business focuses on the production and selling of improved seeds: "For the purpose of my business stability, I will increase the quality of products with international standards, be self-dependent financially, and increase the varieties of seed for an increase in target market and attracting new markets."

Nearly half of all respondents viewed the chance to improve product quality as a perceived benefit of internationalisation positively, albeit with some trepidation about their ability to do so without greater government support, which is absent in the current warlord economy. One respondent mentioned using internationalisation to obtain external quality certification, while another one suggested that partnering with foreign entities could lead to an opportunity for greater innovation. Therefore, it appears that a major perceived benefit of internationalisation to Afghan family business leaders is the opportunity to escape the low standards expected domestically, to establish legitimacy and credibility of the company and to enhance the product market reputation of the business.

From an institutional theory perspective, it is logical that Afghan family businesses seek legitimacy outside of the country in global markets as a means of escape from the institutional voids in Afghanistan. This is consistent with Scott (2001), who argues that professional standards for operations can act as a normative influence on institutions, and Selznick (1996), who finds that the adoption of best practices is a way of obtaining external legitimacy. Given that there is no institutional support for quality standards in Afghanistan, Afghan families seek security by following best practices established outside of the country, in the hopes that their products will be attractive to a global market. Where there is no institutional regulation to control Afghan family businesses' product quality, this void 
is filled by co-opting global standards. Three respondents mentioned that the foreign market may be more stable or exhibit greater demand than the Afghan market; another felt that internationalisation could help develop their company's position in the global supply chain. As a business leader in the agricultural sector stated: "If the government provides us the opportunity and platform, we are willing to internationalise, as Afghanistan has better quality of vegetables and fruits. We have other traders who buy from us and export it to foreign countries."

Another interviewee identified a theme that drives the interest in internationalisation unrelated to institutional voids: national pride. Several respondents indicated that internationalisation would allow Afghans to demonstrate what their culture has to offer to the world, revealing pride in national competencies. As stated by one business leader: "The carpets of Afghanistan are famous worldwide. We already have a great demand in Europe and America. We only need to deliver the carpets to every corner of the world." Another one responded: "As you know, Afghanistan honey is one of the best ranked honey in the world; therefore, we try our best to find our place in the global market."

Our second research question assesses which institutional voids in the domestic ecosystem are viewed as critical to escape by the Afghan family business leaders surveyed. A summary of themes uncovered is provided in Table 4.

Table 4. Institutional voids promoting internationalisation according to Afghan family business leaders

\begin{tabular}{|l|c|c|}
\hline \multicolumn{1}{|c|}{$\begin{array}{c}\text { External Institutional Voids } \\
\text { (outside of the control of the family) }\end{array}$} & $\begin{array}{c}\text { Number } \\
\text { of responses }\end{array}$ & $\begin{array}{c}\% \text { of Firms Identifying } \\
\text { the Challenge }\end{array}$ \\
\hline Security & 10 & $66.67 \%$ \\
\hline Lack of government support & 9 & $60.00 \%$ \\
\hline Corruption/the mafia & 9 & $60.00 \%$ \\
\hline Lack of resources & 8 & $53.33 \%$ \\
\hline Infrastructure & 7 & $46.67 \%$ \\
\hline Import substitution & 3 & $20.00 \%$ \\
\hline Instability & 3 & $20.00 \%$ \\
\hline Limited domestic market & 3 & $20.00 \%$ \\
\hline Poverty & 1 & $6.67 \%$ \\
\hline Social limitations related to gender & 1 & $6.67 \%$ \\
\hline Internal Challenges (In family business) & 10 & \\
\hline Access to capital & 5 & $36.67 \%$ \\
\hline Lack of partner & 2 & $13.33 \%$ \\
\hline Knowledge/Skilled labour & 2 & $13.33 \%$ \\
\hline Inappropriate tax payment systems & 2 & $13.33 \%$ \\
\hline Ability to meet international quality standards/Technology & 1 & $6.67 \%$ \\
\hline Lack of experience & 1 & $6.67 \%$ \\
\hline Lack of interest/Resistance from management team & \\
\hline
\end{tabular}

Source: own study.

The institutional voids that Afghan family businesses face are related to the lack of security, resources, and infrastructure, alongside corruption. The most common theme was physical security, with $60 \%$ of surveyed business owners expressing worries re- 
garding safety, especially in the provinces. This is consistent with the image of the Afghanistan as a highly fragmented, tribal, war-torn nation that continually faces internal uprisings and routine suicide bombings.

Related to security, the primary concern of most of the surveyed business leaders is the value the company's success brings to the family and - as a result - the family business leaders are concerned about the security of their family members. For this reason, they hesitate to include their family members in the businesses, where they face many hardships and security problems. These companies are willing to increase their value through geographic expansion, but this is risky when expansion even internally, to other provinces, can be deadly. One of the participants, Malika, who is the owner of a construction and road design company, mentioned that many projects are revoked due to the contingencies caused by security concerns in the provinces. They perceive that these problems would be mitigated in environments with greater security.

Another common theme was the warlord economy, which has filled the voids abandoned by legitimate sector functions of the state, popularly known as the Mafia. Nearly all of the businesses cited the Mafia and official corruption as a problem at home driving international expansion, while corruption was documented nearly as often as security concerns. A business leader in the soya/flour production sector stated that, "The existence of the Mafia, ministerial corruption, security issues, and the lack of lending agencies is a huge obstacle in front of Afghan businesses." Afghan family business leaders reported "being choked by the Mafia and ministerial corruption." According to Abdul, family business leader of a construction and engineering firm, his family's intention to internationalise arises from a variety of limitations in Afghanistan: "Regarding the limitations in the local environment, the huge challenges we face are disloyalty at work, administration corruption, security issues, and poverty; security and instability are the major reason for the failure of family-owned businesses here."

Corruption is the major obstacle behind the failure of economic development of the country, and one of the main reasons for corruption in business in Kabul is the centralised system used in many of the ministries, which creates barriers for businesses who lack supporters in the ministries to obtain funding and expand their business. This is consistent with the findings of Mashal (2014) of the Small and Medium Enterprises Development and Regional Trade Agency in Afghanistan, who documents that - for SMEs - the mafia and corruption are one of the major challenges for the SMEs. Mashal states that, "For Afghan traders, challenges related to transportation, border transit, and corruption at customs and taxation offices impede growth."

Corruption in Afghan businesses impacts the quality of work, and results in the lack of motivation to develop beyond the immediate local market, not to mention expand into foreign markets. Most of the businesses interviewed revealed that the foundation of the corruption in businesses appeared in the government sectors, and this corruption instils Afghan entrepreneurs with a sense of futility and hopelessness. Indeed, Afghanistan ranks number 169 out of 175 countries, as one of the worst countries in the world in terms of corruption based on Transparency International's Corruptions Perceptions Index.

Related to corruption and the Mafia are unethical practices in the process of bidding on projects. Specifically, construction related companies had problems with unethical competition in the construction businesses; many of the companies were concerned with 
uneven competition because of self-dealing through private relationships with governmental authorities or officials who support them indirectly. When asked about constraints for her business to be successful in the local market that could be overcome through internationalisation, one of the construction business owners, Malika, answered: "The unethical competition between companies is the major problem restraining our company to be successful in bidding for projects and getting new projects for the purpose of success and company's retention in the market."

The lack of access to resources was also identified as a major concern, consistent with Arregle et al.'s (2017) meta-analysis of family business internationalisation. Although, for Afghan business leaders surveyed in this study, the resource constraints are external to the firm, not internal to the family. While Afghanistan has become dependent on aid from international organisations and donors, the decline in global development funding deepened since 2014, while government support became the focal point of businesses who expect government to assist with businesses expansion, growth, and stability. Many of the interviewed businesses exhibited resentment towards the government, because of its lack of interest and attention to the needs of family businesses. Considering challenges as a whole, $60 \%$ of the surveyed businesses had concerns about the lack of government support due to which they were unable to achieve their business goals. Some interviewees hoped for assistance from the Afghan government and Afghan embassies in different countries to help them establish networks with foreign business leaders.

Resources are one of the main drivers of the business and, in Afghanistan, most of businesses are forced to import resources from neighbouring countries, which can be financially inefficient due to high supply costs and the low quality of materials. Due to decades of wars in Afghanistan, access to many resources declined, especially in the agriculture products, one of the major strengths of Afghan production. Nasrat and Karimi (2016) explain the major challenges the carpet industry faces that affect the industry's stability in the economic market of Afghanistan: "Only $40 \%$ of domestic raw materials (e.g. wool) are used in carpet weaving. The remaining raw materials are imported from countries such as Iraq, New Zealand, Belgium, Saudi Arab and Pakistan".

Among the surveyed business leaders, over half cited resource limitations and the inability to obtain raw materials and other financial resources within Afghanistan as factors encouraging internationalisation. The leader of a successful family tailoring business, Nasir, mentioned that his family must import fabrics from the neighbouring countries such as Iran, Turkey, and Pakistan, because Afghanistan lacks domestic fabric production, despite having a more developed agricultural sector. Mohammedd Ilyas Faizi, whose company imports medicines and medical equipment from the Western countries, also had concerns regarding domestic resources. These problems could be resolved by operating in neighbouring countries, where the Mafia does not control imports or levy bribes on importing companies.

Another documented institutional void is related to infrastructure. Afghanistan lacks a sufficient amount of electricity due to the uneven conditions and prolonged war. SMFEs face a lack of power, water, sewerage, and waste disposal. Sumaya Rezaie, who is an entrepreneur of a bakery for industrial breads, says that, "The big problem we face is security, the second one is that government doesn't have any facilities for entrepreneurs like land, water, or electricity." The electricity problem exists not only in the capital city of Kabul but is severe in other provinces, including the major cities of Mazaar, Herat, and Jalalabad. 
In other words, internationalisation offers a means of escape from the domestic environment: escape from poverty, instability, corruption - as one would expect - but also from the low standards of life and weak physical, technological, and human capital infrastructure. However, while internationalisation may be of great interest to family businesses, planning to do so may be a luxury they do not have, because survival, or stability, must be the top concern of Afghan family business leaders, unless they perceive crossborder activity can contribute positively to the success of the business and their family. As a result, this hardship appears to generate even greater commitment of Afghan family business leaders. $90 \%$ of the business leaders in this study revealed plans that focus on business stability, developed with the use of resources available in the family, which they felt could be implemented through internationalisation. As Sherman (2018) states, internal business environment and challenges are such that influence business operations and expansion, while external environment factors and challenges are such over which businesses have little to no control. This analysis found that external institutional voids are more frequently mentioned by family business leaders as reasons to internationalise than internal challenges in the business.

Our third research question addresses the preferred internationalisation process by Afghan family business leaders. As previously mentioned, three of the fifteen business leaders have foreign operations. Moreover, five of the fifteen business leaders already have a potential or existing foreign partner in a culturally similar country, with whom they discussed establishing cross-border activities - generally in Pakistan and Iran - to ultimately establish extensive joint business operations. For thirteen of the surveyed firms, culturally similar countries like Iran or Pakistan were cited as the most likely location for the expansion, if the firm internationalised. Of the Afghan business leaders who stated that they intend to internationalise, most expressed keen interest in working with a foreign partner and in establishing relationships with foreign entities for the purposes of business development and trade, in part to compensate for the deficits in human capital resources identified by Arregle et al. (2017) as barriers to internationalisation. One of the responses was: "I would prefer to first proceed stepwise to neighbouring countries, due to the lower level of risk if the business fails."

Table 5. Desired internationalisation strategies

\begin{tabular}{|l|c|c|}
\hline \multicolumn{1}{|c|}{ Strategy } & $\begin{array}{c}\text { Number of firms report- } \\
\text { ing strategy as ideal }\end{array}$ & $\begin{array}{c}\text { \% of firms reporting } \\
\text { the strategy as ideal }\end{array}$ \\
\hline Staged Internationalisation & 5 & $33.33 \%$ \\
\hline Network strategy (alliance/JV) & 5 & $33.33 \%$ \\
\hline Born Global & 2 & $13.33 \%$ \\
\hline Export & 1 & $6.67 \%$ \\
\hline M\&A & 1 & $6.67 \%$ \\
\hline Office/Branch & 0 & $0.00 \%$ \\
\hline Unwilling to internationalise at this point in time & 3 & $20.00 \%$ \\
\hline
\end{tabular}

Source: own study.

Around $33 \%$ of other business leaders indicated that they prefer to internationalise using network models (see Table 5). First developed by Johanson and Matsson (1988), the network model argues that the firm develops relations with international companies to achieve organisational goals and objectives in the foreign market. This networking will help 
firms remain stable in the new market and to more easily access target market information. As one business owner said: "Before internationalising, we should build relations with other companies, we should know where are we investing, and we should analyse whether we can get profit and be stable in the foreign market or not." Another business owner stated that: "First we must plan a joint venture with a company outside of our country to acquaint ourselves with global standards of production and, then, we try that the company certified from international agencies and hand international business permit. What is more, our company is trying to forecast some cost for attending international business training to consider demand of target market."

Considering possible globalisation strategies, another family business leader argued that a local partner in a joint venture would be helpful to obtain knowledge of the local market: "The first challenge in our way is to find a good market for investment, then we will find a local partner who will be familiar with the local market and establish a joint venture with them."

The sample also contains two born global firms, who internationalised their business shortly after starting their operations. One of largest tailoring companies in Kabul, Poshak Istanbul, internationalised to Iran and Turkey. First, it started its operations in those countries and then internalised by starting its operations in different branches in Kabul. On the other hand, one of the surveyed entrepreneurs chose to internationalise through a stagewise process even though she preferred to be a born global. However, she recognised that - as an early entrant - the probability of success for her internationalisation are very low, unless she could quickly develop the required competencies on her own. The surveyed entrepreneurs had knowledge and interest in a variety of global expansion strategies, and they appeared to exhibit intimate knowledge of the requisite skills for specific internationalisation strategies, thus reinforcing the importance of personal dialogue with entrepreneurs in academic entrepreneurship and international business research.

To summarise, this study assessed the institutional voids that promote internationalisation of Afghan family business leaders, about which little has been published, despite the 100 billion USD in foreign aid for security and economic development over the past decade. Thus far, it appears that supranational entities were very active in "doing something" to improve living conditions in Afghanistan, but this has not translated into tangible benefits for Afghan family business owners, possibly because no one has endeavoured to ask family business owners what kind of support they actually need to internationalise.

We found that, consistent with Claver, Rienda, and Quer (2009), Afghan SMFE owners are greatly interested in internationalisation and perceive many benefits in terms of improvement in product quality and establishing reputational capital in foreign markets. In a sense, this finding is interesting, because it indicates that - when the home country market is so inhospitable - the desire for internationalisation overcomes the perceived trade-off of dilution of family control. This contradicts non-conflict family business situations examined by Arregle et al. (2017), which indicate that family-owned firms prefer not to involve nonfamily resources, even if it results in suboptimal outcomes. Moreover, family business leaders express optimism regarding the potential of cross-border partnerships in culturally and linguistically similar neighbouring countries, which agrees with the findings of Antoncic and Hisrich (2000). In other words, consistent with Gomez-Mejia et al. (2007), there are geographically determined constraints imposed on Afghan family businesses by non-existent, 
inefficient, or perversely incentivised institutions, from which internationalisation is a means of escape. Moreover, our results agree with Schoppa (2008). In fact, given the warlord economy described by Sanders and Weitzel (2013), growth in the home country market may be perceived as a threat to the economic and political power of Afghanistan, supporting the conjecture that internationalisation has additional value to conflict zone family businesses.

However, family businesses often lack the human capital resource base to internationalise, thus making foreign operations and partnerships appear risky. This partly yields to some hesitation on behalf of family business leaders regarding internationalisation, who argue that more support from outside of the family is required for them to engage in cross border operations. This finding agrees with Graves and Thomas (2008). Future research could address entrepreneurial intention in a more comprehensive manner. However, the environment for entrepreneurship in Afghanistan is so weak that many entrepreneurs depend on their businesses for survival, which is continually threatened, resulting in emotional fatigue and risk aversion. They do not have the opportunity to bring in foreign investors or professional managers, as companies examined in the West do (see e.g. the discussion regarding German family-owned firms in Calabrò et al., 2017). They overwhelmingly cited corruption at all levels of institutions, the lack of personal security, and the lack of government support as the key barriers to expanding across borders. Furthermore, they lack the external institutional framework that exists in the developed world, including an adequate physical infrastructure, personal security, and access to financial resources to feel comfortable in their endeavours. Moreover, they also lack the internal infrastructure for internationalisation, including liquidity/financial constraints, knowledge about foreign firms, skilled labour, and face disincentives from the tax payment system in Afghanistan.

As stated by IFERA (2003), opportunities for internationalisation of SMEs, including family businesses (or SMFEs) can strongly influence a country's GDP. On the other hand, the deterioration conditions facing the SMFEs could negatively affect the country's income. Identifying strategies for SMFE internationalisation is of great importance, as Afghanistan requires a strong economic foundation for development.

Arregle et al. (2017) argue that factors such as resources internal to the family and trust of foreign entities impact internationalisation strategies. They observe that family-owned firms avoid obtaining resources external to the family. In the case of the Afghan environment, trust has been continually undermined to the point that tribalism predominates, and the Mafia seeks to propagate unrest among ethnic and religious groups in order to retain its grip on resources and power. Accordingly, we find that resource deficits are cited by most Afghan SMFE owners as a significant barrier to internationalisation. Therefore, a theoretical extension of conflict zone family entrepreneurship theory could draw in the scarcity of resources that exist in these environments and domination of family interests by warlord entrepreneurs.

Our results are not generalisable to only Afghan SMFEs. Much of the world survives in conflict-driven environments with high rates of poverty and low educational levels, where the SMFE is the predominant organisational form. In order to promote economic growth and development of these countries, including Afghanistan, it is useful to have first-hand narratives regarding perceived barriers to the development of international markets by SMFEs. 


\section{CONCLUSIONS}

Institutional theory yields explanations for organisational behaviour not explained by standard economic theory (DiMaggio \& Powell, 1991). Realistically, from an institutional theory perspective, organisational behaviours will remain in place to support the warlord economy and little will be done to address the development of entities of commerce through the resolution of physical security considerations, the resolution of widespread corruption, or the establishment of democratic processes in Afghan political environment. Kabul will remain the "city of concrete blast T-walls." The institutional landscape is likely to remain incomplete or co-opted by perverse incentives, as the Allied forces that currently support Afghan security withdraw, and the security landscape will likely worsen. Rent-seeking by public officials is the norm, and there is no incentive to change.

To escape these terrible operating conditions caused by vast institutional voids, Afghan family-owned firms require the support of structures internal to the family: loyalty, trust, and socioeconomic wealth objectives. While for some family-owned firms, constraints on financial capital and human capital resources - such as professional management - may restrict their ability to internationalise, many family-owned businesses in the West have not needed to develop the resilience that their conflict zone counterparts have, as they do not confront suicide bombings, famine, "disappearances," and blackouts in the ordinary course of business.

Our findings indicate that - despite a scarcity of professional management resources Afghan family business leaders are highly interested in using internationalisation to escape from the institutional voids they face in the local environment. Furthermore, common themes regarding legitimacy in global markets and national pride underscore sampled business leaders' desire to internationalise. Our study extends the literature relating to institutional theory by describing the institutional voids that push conflict zone family businesses to internationalise, but also a non-economic explanation of the hurdles conflict zone family business leaders face in warlord economies, such as corruption, security concerns, and the chronic lack of resources in poor and aid-reliant countries like Afghanistan. Furthermore, we extend the family business literature by indicating that the majority of conflict zone family business leaders who expressed the interest in internationalisation believe that the appropriate way to proceed with internationalisation is to follow a stepwise process, so that one can draw upon both strengths inherent to the family and also engage in organisational learning through relationships with family businesses in the higher institutional quality of neighbouring countries with similar cultures.

For the donor community or supranational entities that operate in Afghanistan, it is essential to understand how capital can effectively be deployed so that there is some hope for these SMFE owners to expand their markets. Based on Bullough et al. (2017), the damaging psychological impacts of war on entrepreneurial intention can be mitigated to the extent that entrepreneurial resilience can be cultivated through entrepreneurship training. Where internationalisation can begin is with development assistant directed at the development of human capital, in the local language, brought directly to the leaders of family businesses. Such human capital development should include training for employees regarding efficient production, and for business leaders regarding educational resources related to professional management in business disciplines. Secondly, production requires investment in power and 
technology, so donor funds could perhaps be allocated towards purchasing generators and modern business equipment along with training to use this technology. Moreover, if the security situation deteriorates, collective funding for private security shared by several SMFEs in the same geographic area may be of use. From this starting point of basic business literacy, SMFE leaders can then begin the process of establishing long-term plans related to the development of a foreign market entry strategy.

Our research contains several limitations. One of the challenges was the unavailability of appropriate data, as there are very few studies done on the internationalisation of SMFEs in Afghanistan. Due to the lack of secondary data, we use qualitative data analysis to learn from the experiences of Afghan SMFE managers. Data collection and interviews were very challenging due to the uncertainties related to unfavourable security conditions. Obtaining more detailed information was also difficult due to time limitations and busy schedules of the family business leaders. The study has only been conducted based on the businesses in Kabul city; they may differ in other cities.

We hope this will be a starting point for subsequent research on the internationalisation interests, strategies, and outcomes of conflict zone family businesses beyond the Afghan environment. Given that an estimated one in six children in the world today is growing up exposed to violent conflict, an understanding of the psychosocial processes underlying family business in war zones is important. Future research could uncover the dynamic between resilience and family business outcomes in conflict zones or explain how family businesses in conflict zones leverage family resources to internationalise successfully. What would also be useful would be the understanding of the dynamics in family businesses in supporting the process of recovering from "institutional forgetting" through the exposure to new ideas offered by internationalisation. Finally, an understanding of how family-owned businesses can contribute to peacebuilding efforts is relevant to the conflicts in Syria, Sudan, Yemen, and Iraq.

\section{REFERENCES}

Ahmad, J. (2018, September 18). The Mafia that Threatens Afghanistan. Wall Street Journal. Retrieved from https://www.wsj.com/articles/the-mafia-that-threatens-afghanistan-1537397750 on September 20, 2018.

Arregle, J.L., Duran, P., Hitt, M.A., \& Van Essen, M. (2017). Why is family firms' internationalization unique? A meta-analysis. Entrepreneurship Theory and Practice, 41(5), 801-831.

Anderson, R., \& Reeb, D. (2003). Founding-Family Ownership and Firm Performance: Evidence from the S\&P 500. The Journal of Finance, 58(3), 1301-1328. Retrieved from www.jstor.org/stable/3094581 on August 5, 2018.

Antoncic, B., \& Hisrich, R. (2000). Intrapreneurship modeling in transition economies: A comparison of Slovenia and the United States. Journal of Developmental Entrepreneurship, 5(1), 21-40.

Banalieva, E.R., Eddleston, K., \& Zellweger, R. (2014). When do family firms have an advantage in transitioning economies? Toward a dynamic institution-based view. Strategic Management Journal, 36(9), 1358-1377.

Bhaumik, S., Driffield, N., \& Pal, S. (2010). Does ownership structure of emerging market firms affect their outward FDI? The case of the Indian automotive and pharmaceutical sectors. Journal of International Business Studies, 41(3), 437-450. 
Bouges, F.F. (2013). Internationalization of family businesses in Saudi Arabia (Doctoral dissertation). Retrieved from https://search-proquest-com.ezproxy.hct.ac.ae/docview/1473909570?accountid=1215 on June 5, 2019.

Bullough, A., Renko, M., \& Myatt, T. (2017). Danger Zone Entrepreneurs: The Importance of Resilience and Self-Efficacy for Entrepreneurial Intentions. Entrepreneurship Theory and Practice, 38(3), 473-499.

Calabrò, A., Brogi, M., \& Torchia, M. (2016). What does really matter in the internationalization of small and Medium-Sized family businesses?. Journal of Small Business Management, 54(2), 679-696.

Calabrò, A., Torchia, M., Pukall, T., \& Mussolino, D. (2013). The influence of ownership structure and board strategic involvement on international sales: The moderating effect of family in-volvement. International Business Review, 22(3), 509-523.

Calabrò, A., Campopiano, G., Basco, R., \& Pukall, T. (2017). Governance structure and internationalization of family-controlled firms: The mediating role of international entrepreneurial orientation. European Management Journal, 35(2), 238-248.

Carney, M. (2005). Corporate governance and competitive advantage in family-controlled firms. Entrepreneurship Theory and Practice, 36(6), 1115-1143.

Carney, M., Duran, P., van Essen, M., \& Shapiro, D. (2017). Family firms, internationalization, and national competitiveness: does family firm prevalence matter?. Journal of Family Business Strategy, 8(1), 123-136.

Casson, M.M. (1999). The economics of the family firm. Scandinavian Economic History Review, 47(1), 10-23.

Caves, R.E. (1996). Multinational Enterprise and Economic Analysis (2nd ed.).Cambridge University Press: Cambridge.

Chrisman, J.J., Chua, J.H., \& Litz, R.A. (2004). Comparing the agency costs of family and nonfamily firms: Conceptual issues and exploratory evidence. Entrepreneurship Theory and Practice, 28(4), 335-354.

Chua, J.H., Chrisman, J.J., \& Sharma, P. (1999). Defining the family business by behavior. Entrepreneurship theory and practice, 23(4), 19-39.

Claver, E., Rienda, L., \& Quer, D. (2009). Family Firms' International Commitment: The Influence of Family-Related Factors. Family Business Review, 22(2), 125-135. https://doi.org/10.1177/0894486508330054

Creswell, J.W. (2013). Qualitative inquiry and research design: choosing among five approaches. Thousand Oaks, CA: Sage.

De Massis, A., Kotlar, J., Mazzola, P., Minola, T., \& Sciascia, S. (2018a). Conflicting selves: family owners' multiple goals and self-control agency problems in private firms. Entrepreneurship Theory and Practice, 42(3), 362-389. https:/doi.org/10.1111/etap.12257

De Massis, A., Kotlar, J., Wright, M., \& Kellermanns, F. (2018b). Sector-based entrepreneurial capabilities and the promise of sector studies in entrepreneurship. Entrepreneurship Theory and Practice, 42(1), 3-23. https://doi.org/10.1177/1042258717740548

Denis, D., Denis, D., \& Sarin A. (1999). Agency problems, equity ownership, and corporate diversification. Journal of Finance, 52(1), 135-160.

DiMaggio, P.J., \& Powell, W.W. (1991). Introduction. In W.W. Powell \& P.J. DiMaggio (Eds.), The New Institutionalism in Organizational Analysis (pp. 1-38). Chicago: University of Chicago Press.

Dunning, J.H. (1996). Multinational Enterprises and the Global Economy. Addison-Wesley: Reading.

Dupree, L. (1997). Afghanistan (2nd ed.). Karachi. Oxford: Oxford University Press. 
Fisher, C. (2013). The (changing) Role of Family among Afghan Communities in Britain and Germany. THEMIS International Migration Conference Examining Migration Dynamics: Networks and Beyond. University of Oxford, UK.

Global Passport Power (2019). Retrieved from https://www.passportindex.org/byRank.php on August 5, 2018.

Gomez-Mejia, L., Haynes, K.T., Núñez-Nickel, M., Jacobson, K.J.L., \& Moyano-Fuentes, J. (2007). Socioemotional Wealth and Business Risks in Family-Controlled Firms: Evidence from Spanish OIive Oil Mills. Administrative Science Quarterly, 52(1), 106-137.

Gomez-Mejia, L., Makri, M., \& Larraza-Kintana, M. (2010). Diversification decisions in family-controlled firms. Journal of Management Studies, 47(2), 223-52.

Gordon, R.H., \& Hines Jr., J.R. (2002). International taxation (NBER Working Paper Series). NBER: Cambridge, MA.

Graves, C., \& Thomas, J. (2008). Determinants of the internationalization pathways of family firms: An examination of family influence. Family Business Review, 21(2), 151-167.

Hennart, J.F. (2014). The accidental internationalists: a theory of born globals. Entrepreneurship Theory and Practice, 38(1), 117-135.

Hennart, J.F., Majocchi, A., \& Forlani, E. (2017). The myth of the stay-at-home family firm: how family-managed SMEs can overcome their internationalization limitations. Journal of International Business Studies, 50(5), 758-782. https://doi.org/10.1057/s41267-017-0091-y

Hernández, V., Nieto, M.J., Boellis, A. (2018). The asymmetric effect of institutional distance on international location: Family versus nonfamily firms. Global Strategy Journal, 8(1), 22-45.

Family Businesses Dominate: International Family Enterprise Research Academy (IFERA). (2003). Family Business Review, 16(4), 235-240. https://doi.org/10.1177/08944865030160040201

Javalgi, R.R.G., \& Todd, P.R. (2011). Entrepreneurial orientation, management commitment, and human capital: The internationalization of SMEs in India. Journal of Business Research, 64(9), 1004-1010.

Johanson, J., \& Mattsson, L.G. (1988). Internationalization in Industrial Systems - A Network Approach. In N. Hood \& J. Vahlne (Eds.), Strategies in Global Competition (pp. 287-314). New York: Croom Helm.

Kemppainen, K. (2011). Family business internationalization opportunities and obstacles from an entrepreneur's perspective - a case study of the creative industry (Master's Thesis). University of Jyväskylä, Finland.

Kothari, C.R. (2004). Research Methodology: Methods and Techniques (2nd Edition). New Delhi: New Age International Publishers.

Kotlar, J., \& De Massis, A. (2013). Goal setting in family firms: goal diversity, social interactions, and collective commitment to family-centered goals. Entrepreneurship Theory and Practice, 37(6), 1263-1288.

Leaptrott, J. (2005). An Institutional Theory View of the Family Business. Family Business Review, 18(3), 215-228.

Maguen, S., Papa, A., \& Litz, B.T. (2008). Coping with the threat of terrorism: A review. Anxiety, Stress, \& Coping, 21(1), 15-55.

Mair, J., \& Marti, I. (2009), Entrepreneurship in and around institutional voids: a case study from Bangladesh. Journal of Business Venturing, 24(5), 419-435.

Marpsat, M., \& Razafindratsima, N. (2010). Survey Methods for Hard-to-Reach Populations: Introduction to the Special Issue. Methodological Innovations Online, 5(2), 3-16. https://doi.org/10.4256/mio.2010.0014 
Mashal, M. (2014). Small and Medium Enterprises Development and Regional Trade in Afghanistan. Retrieved from https://papers.ssrn.com/sol3/papers.cfm?abstract_id=2943895 on August 5, 2018.

Mehlum, H., Moene, K., \& Torvik, R. (2003). Predator or Prey? Parasitic Enterprises in Economic Development. European Economic Review, 47, 275-94.

Meyer, J.W., \& Rowan, B. (1977). Institutionalized Organizations: Formal Structure as Myth and Ceremony. American Journal of Sociology, 83(2), 340-363.

Miller, D., \& Le Breton-Miller, I. (2005). Managing for the Long Run: Lessons in Competitive Advantage from Great Family Businesses. Boston: Harvard Business School Press.

Muller, P. (2011). Scattered Families: Transnational Family Life of Afghan Refugees in the Netherlands in the Light of the Human Rights-based Protection of the Family. Journal of Refugee Studies, 24(1), 210-211, https://doi.org/10.1093/jrs/feq059

Mudalige, M. (2015). A dynamic capabilities perspective of internationalization and performance of SMEs in Sri lanka (Phd Research). Othman Yeop Abdullah Graduate School of Business, Universiti Utara, Malaysia.

Nasrat, S., \& Karimi, A.T. (2016). The Afghan Carpet Industry: Issues and Challenges. Retrieved from https://www.unwe.bg/uploads/Alternatives/Carpet_Industry_i_4_2016_05.01.2017.pdf on September 1, 2018.

Okoroafo, S.C. (2010). Family Businesses' Views on Internationalization: Do They Differ by Generation?. International Business Research, 3(1), 22-28.

Omidian, P.A. (1996). Aging and Family in an Afghan Refugee Community: Transitions and Transformations. New York: Garland Pub.

Peters, B. (2012). Institutional Theory in Political Science: the New Institutionalism. New York: Bloomsbury Publishing.

Poutziouris, P., Smyrnios, K., \& Klein, S. (2008). Handbook of research on family business. Cheltelham: Edward Elgar Publishing.

Poza, E.J. (2013). Family business (4th ed.). OH, South-Western: Cengage Learning Publishers.

Pukall, T.J., \& Calabrò, A. (2014). The internationalization of family firms: A critical review and integrative model. Family Business Review, 27(2), 103-125.

Sanders, M., \& Weitzel, U. (2013). Misallocation of Entrepreneurial Talent in Postconflict Environments. Journal of Conflict Resolution, 57(1), 41-64.

Sherman, F. (2018). What are Internal \& External Environmental Factors That Affect Business. Houston Chronicle. Retrieved from https://smallbusiness.chron.com/internal-external-environmental-factors-affect-business-69474.html on August 10, 2018.

Schoppa, L.J. (2008) Race for the exits: the unraveling of Japan's system of social protection. New York: Cornell University Press.

Scott, W.R. (2001). Institutions and organizations (2nd ed). Thousand Oaks, CA: Sage.

Seale, C. (1999). The Quality of Qualitative Research. London: SAGE.

Selznick, P. (1996). Institutionalism "old" and "new." Administrative Science Quarterly, 41, 270-277.

Short, J.C., Payne, G.T., Brigham, K.H., Lumpkin, G., \& Broberg, J. C. (2009). Family firms and entrepreneurial orientation in publicly traded firms a comparative analysis of the S\&P 500. Family Business Review, 22(1), 9-24.

Smith, D.J. (2009). Decisions, Desires and Diversity: Marriage Practices in Afghanistan. In Issue Paper Series. Kabul: Afghanistan Research and Evaluation Unit (AREU). 
Varghese, J. (2015). Five stages of international market development. Retrieved from http://www.tradeready.ca/2015/fittskills-refresher/5-stages-international-market-development/ on September 12, 2018.

Verbeke, A., \& Kano, L. (2012). Transaction cost economics (TCE) and the family firm. Entrepreneurship Theory and Practice, 36(6), 1183-1205.

Vogt, W.P. (1999). Dictionary of Statistics and Methodology: A Non-Technical Guide for the Social Sciences (2nd ed.). London: Sage.

World Bank (2019). Retrieved from https://data.worldbank.org/country/afghanistan on August 21, 2019.

Yamanoi, J., \& Asaba, S. (2018). The impact of family ownership on establishment and ownership modes in foreign direct investment: The moderating role of corruption in host countries. Global Strategy Journal, 8, 106-135.

Yang, Z., \& Su, C. (2014). Institutional theory in business marketing: A conceptual framework and future directions. Industrial Marketing Management, 43(5), 721-725.

Yin, R. (2003). Case study research: design and methods (3rd ed). Thousand Oaks, CA: Sage.

\section{Authors}

The contribution share of authors is equal and amounted to $25 \%$ each of them.

\section{Muska Hanify}

MBA from the American University of Afghanistan and the Regional Economic Development Manager at Capital Region Independent Development Authority-CRIDA, Afghanistan.

Correspondence to: Muska Hanify, Regional Economic Development Manager at Capital Region Independent Development Authority-CRIDA, Afghanistan, e-mail: mhanify.mba@auaf.edu.af

\section{Omar Al Serhan}

PhD in Marketing Management, Chair of Business Department and an Assistant Professor of Business, Faculty of Business Higher Colleges of Technology, Ras Al-Khaimah Campuses, United Arab Emirates, Associate Editor of Transnational Marketing Journal (Scopus), member of editorial boards of International Journal of Business Performance Management (Scopus), International Journal of Islamic Marketing and Branding and Transnational Marketing Journal. Additionally, Dr Al Serhan is an organizing committee member for the Migration Conference and the Global Islamic Marketing Conference. Research interest: Transnational Arabs consumers, brand loyalty and boycotting behaviour, transnational marketing and Islamic hospitality, Innovation and Entrepreneurship.

Correspondence to: Dr Omar Al Serhan, Higher Colleges of Technology, Ras Al-Khaimah, United Arab Emirates. P.O. Box: 4792, Ras Al Khaimah, United Arab Emirates, e-mail: oalserhan@hct.ac.ae ORCID (1) http://orcid.org/0000-0002-0222-1646 


\section{S.W.S.B. Dasanayaka}

$\mathrm{PhD}$ in management and Professor of Management at the Department of Industrial Management in the University of Moratuwa, Sri Lanka. Research interest: International supply chain, operations management and Entrepreneurship. S.W.S.B. Dasanayaka is currently working as a Professor of Management at the Department of Industrial Management in the University of Moratuwa, Sri Lanka.

Correspondence to: Department of Industrial Management in the University of Moratuwa, Sri Lanka, e-mail: sarathd@uom.lk

ORCID (1) http://orcid.org/0000-0002-1584-0673

\section{Kimberley Catherine Gleason}

$\mathrm{PhD}$ and Associate Professor at the School of Business Administration, Department of Finance, American University of Sharjah. Research interest: gender and entrepreneurship, international business and external monitoring of capital market activity.

Correspondence to: Department of Finance, American University of Sharjah, e-mail: kgleason@aus.edu

ORCID (1) http://orcid.org/0000-0001-9231-029X

\section{Copyright and License}

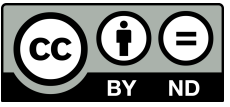

This article is published under the terms of the Creative Commons

Attribution - NoDerivs (CC BY-ND 4.0) License

http://creativecommons.org/licenses/by-nd/4.0/

Published by the Centre for Strategic and International Entrepreneurship - Krakow, Poland 